\title{
Evaluating the nitrification inhibition potential of selected botanicals and their non-target effects
}

\author{
Kumudu K.K. Nawarathna, Warshi S. Dandeniya, Randombage S. Dharmakeerthi, and \\ Priyantha Weerasinghe
}

\begin{abstract}
Nitrification inhibitors (NI) are aimed at improving N-fertilizer use efficiency in cropping systems. This study aimed to assess the nitrification inhibition potential and non-target effects of dry leaf powders (botanicals) of 10 plant species (neem (Azadirachta indica), lantana (Lantana camara), karanda (Pongamia pinnata), Brachiaria (Brachiaria humidicola), cinnamon (Cinnamomum verum), clove (Syzygium aromaticum), wild-sunflower (Tithonia diversifolia), mee (Madhuca longifolia), nutmeg (Myristica fragrans), and pepper (Piper nigram)). The effect of botanicals on the growth of three ammonia oxidizing bacteria isolates (M4, M5, and M7) and $\mathrm{NO}_{3}{ }^{-}$formation in soil were tested in laboratory experiments. In a pot-experiment, botanicals were applied with urea to assess their effect on vegetative-growth of tomato and capsicum. The non-target effects of botanicals on soil bacteria and fungi, and seed germination were assessed separately. Dicyandiamide (DCD) was used as the positive control in all experiments. Only the growth of M7 was significantly suppressed by all botanicals except neem, Brachiaria, and pepper. The highest shoot-biomass of tomato was obtained when urea was applied with pepper. Nitrate leaching from pots was significantly reduced $(P<0.05)$ when urea was added with botanicals except for clove and wild-sunflower at basal-dressing. The abundance of culturable fungi and bacteria were not affected significantly by botanicals while seed germination was reduced significantly and consistently by clove only. From the 10 botanicals tested leaf powders of nutmeg, lantana, cinnamon, mee, and pepper were identified as materials with better potential to suppress nitrification with minimum non-target effects.
\end{abstract}

Key words: nitrification inhibition, botanicals, non-target effects, vegetable crops.

Résumé : Les inhibiteurs de la nitrification accroissent l'efficacité avec laquelle les plantes utilisent les engrais azotés. Les auteurs ont évalué le potentiel inhibiteur et les effets secondaires des feuilles en poudre (produit botanique) de dix plantes [margousier (Azadirachta indica), lantanier (Lantana camara), karanja (Pongamia pinnata), Brachiaria humidicola, cannelier (Cinnamomum verum), giroflier (Syzygium aromaticum), tournesol mexicain (Tithonia diversifolia), Madhuca longifolia, muscadier (Myristica fragrans) et poivrier (Piper nigram)]. Dans cette optique, ils ont vérifié en laboratoire les effets du produit sur la croissance de trois isolats bactériens oxydant l'ammoniaque (M4, M5 et M7) et produisant du $\mathrm{NO}_{3}$ dans le sol. Lors d'une expérience en pot, les auteurs ont appliqué le produit botanique avec de l'urée afin d'en évaluer les effets sur la croissance végétative de la tomate et du poivron. Ils ont estimé séparément les effets secondaires du produit sur les bactéries et les cryptogames du sol, ainsi que sur la germination des semences. Le dicyandiamide (DCD) a servi de témoin positif dans toutes les expériences. Le produit botanique n'arrête de façon significative que la croissance de l'isolat M7, exception faite des feuilles du margousier, de Brachiaria et du poivrier. Le rapport pousse-biomasse le plus élevé pour la tomate a été enregistré avec l'application des feuilles de poivrier. Enrichir l'urée avec un produit botanique diminue significativement $(p<0,05)$ la lixiviation des nitrates, sauf dans le cas des feuilles de giroflier et de celles de tournesol mexicain appliquées à la base. Le produit botanique n'affecte pas de manière significative l'abondance des cryptogames ni des bactéries cultivables, mais les feuilles de giroflier ont sensiblement et constamment réduit la germination des graines. Sur les dix poudres foliaires testées, celles de muscadier, de lantanier, de cannelier, de Madhuca longifolia et de poivrier

Received 10 June 2021. Accepted 4 October 2021.

K.K.K. Nawarathna. Department of Agriculture, Horticultural Crop Research and Development Institute, Gannoruwa, Sri Lanka; Postgraduate Institute of Agriculture, University of Peradeniya, Peradeniya, Sri Lanka.

W.S. Dandeniya and R.S. Dharmakeerthi. Postgraduate Institute of Agriculture, University of Peradeniya, Peradeniya, Sri Lanka; Department of Soil Science, Faculty of Agriculture, University of Peradeniya, Peradeniya, Sri Lanka.

P. Weerasinghe. Ministry of Agriculture, “Govijana Mandiraya”, Rajamalwatta Lane, Battaramulla, Sri Lanka.

Corresponding author: Warshi S. Dandeniya (email: warshisd@agri.pdn.ac.lk).

(C) 2021 The Author(s). This work is licensed under a Creative Commons Attribution 4.0 International License (CC BY 4.0), which permits unrestricted use, distribution, and reproduction in any medium, provided the original author(s) and source are credited. 
présentent un potentiel plus intéressant pour inhiber la nitrification, avec des effets secondaires minimes. [Traduit par la Rédaction]

Mots-clés : inhibition de la nitrification, dérivés des plantes, effets secondaires, cultures maraîchères.

\section{Introduction}

Nitrification inhibitors (NIs) are being used to improve $\mathrm{N}$-fertilizer use efficiency and crop yield (Amberger 1989; Zerulla et al. 2001; Di and Cameron 2004). Dicyandiamide (DCD), 2-chloro-6-trichloromethyl pyridine, 3,4-Dimethylpyrazole phosphate (DMPP), and thiourea are some of the synthetic NIs used in agriculture (Amberger 1989; Weiske et al. 2001; Zerulla et al. 2001). The use of synthetic NIs is limited due to their high cost, lack of availability to farmers and adverse side effects on non-target organisms (Tindaon et al. 2013; Marsden et al. 2015). Recently there is an increased concern of applying synthetic NIs as these could accumulate in the food-chain leading to health hazards (Marsden et al. 2015). Further, synthetic NIs cannot be used in the organic agriculture sector (Norton and Ouyang 2019), which is expanding rapidly in the world. Natural substances with nitrification inhibition properties have gained increasing research interest (Prasad et al. 1989; Majumdar 2002; Gopalakrishnan et al. 2007; Subbarao et al. 2013; Jatana et al. 2020).

The composition and activity of nitrifying microbial communities could vary based on soil conditions as influenced by management practices and inherent properties (Leininger et al. 2006; Prosser and Nicol 2012; Muema et al. 2015). In agricultural soils, nitrification is carried out mainly in two steps by two lithoautotrophic groups of microorganisms. The ammoniaoxidizers are responsible for the rate limiting first step of nitrification, which converts $\mathrm{NH}_{4}{ }^{+}$into $\mathrm{NO}_{2}{ }^{-}$. In the second step, nitrite-oxidizers convert $\mathrm{NO}_{2}{ }^{-}$into $\mathrm{NO}_{3}{ }^{-}$. Synthetic NIs such as DCD and DMPP are known to suppress the activity of lithoautotrophic ammoniaoxidizing bacteria (AOB) (Amberger 1989; Weiske et al. 2001; Gong et al. 2013). However, Gong et al. (2013) reported that DCD was not effective against ammoniaoxidizing archaea (AOA). Plant-based natural NIs are also known to affect both $\mathrm{AOB}$ and nitrite-oxidizing bacteria (NOB), mostly by reducing their abundance and/or retarding their activity (Patra et al. 2006; Norton and Ouyang 2019).

A botanical NI called karanjin, which is a non-fatty component of oil extracted from the seeds of Pongamia glabra Vent. is reported to have equal or more potent nitrification inhibitory activity than DCD (Majumdar 2002). The potential of Bracharia shoots and root exudates to suppress the activity of AOB has been demonstrated previously (Gopalakrishnan et al. 2007;
Subbarao et al. 2013). Different formulations have been developed from neem (Azadirachta indica A.Juss.) to suppress the activity of AOB and NOB (Kumar et al. 2007; Jatana et al. 2020). Since ammonia-oxidizers exhibit niche specialization, such as the dominance of AOA over AOB in acidic soils (Prosser and Nicol 2012), there could be variations in effectiveness of NIs in different soils.

Although NIs are applied with the aim of suppressing nitrifiers, some could have non-target effects by affecting soil enzyme activity, and reducing the culturable bacteria and actinomycete populations in soils (Patra et al. 2006; Tindaon et al. 2013). Therefore, irrespective of being natural or synthetic, there are potential impacts of applying NIs on non-target organisms.

Differences have been observed among vegetable crops with respect to preferential uptake of $\mathrm{NH}_{4}{ }^{+}$and $\mathrm{NO}_{3}{ }^{-}$ (Nawarathna et al. 2021). Thus, a complete inhibition of nitrification in soil may be disadvantageous for the crops that have partiality towards $\mathrm{NO}_{3}{ }^{-}$uptake, and may cause a reduction in $\mathrm{N}$-fertilizer use efficiency. Therefore, the degree of inhibition of nitrifiers, application rate, persistence in the environment and non-target effects are important traits that should be researched related to NIs prior to their release to the environment. Hence, this study was conducted to screen potential botanical NIs from locally available plants to apply in vegetable cultivation based on a series of laboratory bioassays and potexperiments. Further, the non-target effects of the botanical NIs on soil culturable bacteria and fungi, and seed germination were also investigated.

\section{Materials and Method}

\section{Selection of plant species for botanical NI}

The selection of plant species was preliminary done based on the literature. Accordingly, plants researched in other countries for developing NIs such as neem (Azadirachta indica), Lantana (Lantana camara L.), karanda (Pongamia pinnata (L.) Pierre), Brachiaria humidicola (Rendle) Schweick., and mee (Madhuca longifolia (J.Koenig ex L.) J.F.Macbr.) were selected. In addition, plants that have not been previously reported to inhibit nitrification such as cinnamon (Cinnamomum verum J.Presl), clove (Syzygium aromaticum (L.) Merr. \& L.M.Perry), wild-sunflower (Tithonia diversifolia (Hemsl.) A.Gray), nutmeg (Myristica fragrans Houtt.), and pepper (Piper nigrum L.) were also selected. Altogether 10 plant species were selected for the study (Supplementary Table $S 1^{1}$; details plant species selected for testing

${ }^{1}$ Supplementary data are available with the article at https://doi.org/10.1139/cjss-2021-0072. 
for nitrification inhibition potential and their common uses).

\section{Preparation of botanicals}

Approximately $1 \mathrm{~kg}$ (fresh-weight basis) of mature leaves of each selected plant were collected in the first week of January 2018 in the afternoon hours from the vicinity of Horticultural Crop Research and Development Institute (HORDI), Gannoruwa, Sri Lanka $\left(07^{\circ} 19^{\prime} 16.4^{\prime \prime} \mathrm{N}\right.$ and $\left.080^{\circ} 41^{\prime} 40.1^{\prime \prime} \mathrm{E}\right)$ located in the WM2b agro-ecological region (Punyawardena et al. 2003). Leaves were transported to HORDI and cleaned with distilled water to remove dust on the same day and dried at $60{ }^{\circ} \mathrm{C}$ for $24 \mathrm{~h}$ and processed in to a fine powder separately using a grinding mill. Plant powder from each species was stored separately in air tight containers until being used for subsequent analyses. These plant powders are hereinafter referred to as botanicals. Each botanical was analyzed for total nitrogen content using Kjeldal digestion method (Jackson 1958).

\section{Soil sampling and preparations}

Soils for the present study were obtained from two vegetable cultivated fields in Nuwara Eliya $\left(06^{\circ} 56^{\prime}\right.$ $45.0^{\prime \prime} \mathrm{N}$ and $\left.80^{\circ} 47^{\prime} 34.1^{\prime \prime} \mathrm{E}\right)$ and Marassana $\left(07^{\circ} 13^{\prime} 41^{\prime \prime} \mathrm{N}\right.$ and $80^{\circ} 44^{\prime} 27.0^{\prime \prime} \mathrm{E}$ ) located in WU3 and IM3c agroecological regions in Sri Lanka (Punyawardena et al. 2003). The dominant soil type in both these regions are associations of Typic paleudults of Ultisol soil order (Mapa et al. 1999). Soil was collected at 0-20 cm depth from a vegetable cultivated field in each location and transported to HORDI, Gannoruwa. Soils were air dried and passed through a $2 \mathrm{~mm}$ sieve. Air dried soils were analyzed for $\mathrm{pH}$, electrical conductivity (EC), organic $\mathrm{C}$ and active carbon contents. Soil $\mathrm{pH}$ was measured in soil: water suspension of $1: 1$ (Jenway $410^{\circledR} \mathrm{pH}$ meter) and EC in soil: water suspension of 1:5 (Hanna ${ }^{\circledR}$ EC meter). Soil organic carbon (SOC) and active carbon contents were analyzed using modified Walkley and Black method (Nelson and Sommers,1996) and permanganate oxidiazable carbon (POXC) method (Weil et al. 2003), respectively. Field fresh soils were used for microbiological analyses. Total culturable bacteria and fungi were enumerated on $3 \%$ triptic soy agar (TSA) and Rose Bengal agar, respectively, using serial dilutions in spread plate technique. Plates were incubated at $29 \pm 1{ }^{\circ} \mathrm{C}$ and bacterial colony counts were taken $2 \mathrm{~d}$ after inoculation and fungal colonies were counted $6 \mathrm{~d}$ after inoculation. Most probable number (MPN) method as described by Schmidt and Belser (1994) was used to estimate the abundance of ammonia-oxidizers and nitrite-oxidizers. Cultures were incubated in triplicates for $21 \mathrm{~d}$ before making observations. Potential nitrification rate (PNR) of soils was assessed following shaken slurry method (Hart et al. 1994). These two soils were used in all soil incubation studies and potexperiments presented in this paper.

\section{Preparation of ammonia-oxidizing bacteria isolates}

For isolating AOB, soil samples were collected from vegetable cultivated fields in Marassana and Nuwara Eliya regions. Ammonia-oxidizers were enumerated with enrichment culture method using ammonium sulphate $\left(50 \mathrm{mM} \cdot \mathrm{L}^{-1}\right)$ containing $\mathrm{P}$ buffer medium (A-PB) as used in MPN method. Plates containing TSA were inoculated with samples drawn from the liquid cultures proved positive for the presence of ammonia-oxidizers in MPN method to obtain single colonies. Selected colonies were purified and screened for their ability to oxidize $\mathrm{NH}_{4}{ }^{+}$. For this, the isolates of AOB were cultured in A-PB in triplicates and the rate of $\mathrm{NO}_{2}{ }^{-}$production was determined colorimetrically by drawing samples at 4 and $20 \mathrm{~h}$ into incubation (Schmidt and Belser 1994). Accordingly, five isolates positive for $\mathrm{NH}_{4}{ }^{+}$oxidation were obtained and named as M1, M4, M5, M7, and NE1 where the first letter indicate the region from where the soil was obtained (M-Marassana and NE-Nuwara Eliya) and the number indicate the corresponding field sampled. The five isolates were enumerated on agar plates (A-PB plus $15 \mathrm{~g}$ agar $\cdot \mathrm{L}^{-1}$ ) and colony morphology was observed. Seven days old colonies were used in gram-staining. Photomicrographs of cells were captured using a light microscope (Olympus CX41) fitted with a digital camera (Olympus DP21) and a video camera adapter (U-TV0.5XC-3).

\section{Bioassay with ammonia-oxidizing bacteria}

Turbidity test was conducted to test the efficacy of selected botanicals on suppressing the growth of AOB using standard protocols in a bioassay (Manandhar et al. 2019). It is hypothesized that the cell density of the culture is directly proportional to turbidity of the medium (Sutton 2011). The three isolates of AOB (M4, M5 and M7) were selected for the bioassay because they had similar shortrod shaped cell morphology and were collected from vegetable-cultivated soils from Marassana. The isolates were cultured in A-PB medium for $21 \mathrm{~d}$ and culture media was tested for $\mathrm{NO}_{2}{ }^{-}$formation using a spot test (Schmidt and Belser 1994). These broth cultures were used to enumerate the bacterial isolates on TSA using the spread plate technique. After $48 \mathrm{~h}$, a loop full of bacteria culture growing on TSA medium was inoculated into $25 \mathrm{~mL}$ Tryptic Soy broth (TSB) and allowed to grow overnight. This broth culture was used to inoculate a series of culture tubes containing newly prepared TSB by adding $1 \mathrm{~mL}$ of the broth culture to $9 \mathrm{~mL}$ of TSB medium. Stock solutions were prepared for each botanical by suspending plant powder in sterilized distilled water. Ten botanicals were added separately to culture tubes containing TSB and the bacterial isolate at a rate of $0.01 \mathrm{~g} \cdot \mathrm{L}^{-1}$. DCD, a known NI, was added in place of the botanical at a rate of $0.01 \mathrm{~g} \cdot \mathrm{L}^{-1}$ as the positive control. Culture tubes containing only the inoculated TSB medium were used as the negative control. The bioassay was performed with three replicates, incubating the experimental-units at $29 \pm 1{ }^{\circ} \mathrm{C}$. Turbidity of the 
growth medium was measured at $24 \mathrm{~h}$ into incubation using a spectrophotometer (Jenway 6305 UV/VIS Spectrophotometer) at the wave length of $600 \mathrm{~nm}$ (Sutton 2011).

\section{Soil incubation study}

An incubation study was conducted to assess the ability of botanicals to suppress nitrification in two soils collected from Nuwara Eliya and Marassana. The air dried and sieved soils were remoistened to achieve 50\% $(w / w)$ gravimetric water content and incubated for $7 \mathrm{~d}$ to stabilize before applying N-treatments. Each soil was weighed in to polypropylene bottles as $10 \mathrm{~g} \cdot$ bottle $^{-1}$ (dry weight basis) and N-treatments were applied in four replicates after $24 \mathrm{~h}$. Twelve $\mathrm{N}$-treatments were applied with and without ammonium sulfate $\left[\left(\mathrm{NH}_{4}\right)_{2} \mathrm{SO}_{4}\right]$. The N-treatment included each of the ten botanicals applied separately at a rate of $1 \%(w / w)$, DCD applied at a rate of $10 \mathrm{mg} \cdot \mathrm{kg}^{-1}$ (Gong et al. 2013) and zero NI (soil only) control. Ammonium sulfate was added at a rate of $50 \mathrm{mg} \cdot \mathrm{kg}^{-1}$ to the soil (equivalent to $100 \mathrm{~kg}$ of $\left.\left(\mathrm{NH}_{4}\right)_{2} \mathrm{SO}_{4} \cdot \mathrm{ha}^{-1}\right)$. Soils were incubated at $29 \pm 1{ }^{\circ} \mathrm{C}$ and the moisture content was maintained at $50 \%(\mathrm{w} / \mathrm{w}$ basis) throughout the incubation period. At $48 \mathrm{~h}$ after applying $\mathrm{N}$-treatments, $\mathrm{NO}_{3}{ }^{-}$was extracted with potassium chloride and analyzed following the method described by Cataldo et al. (1975).

\section{Planthouse pot experiments}

Planthouse in HORDI, Gannoruwa was used for the study from March to June 2018. The planthouse had natural lighting and good ventilation, and the temperature and air-flow were not regulated artificially. The mean annual temperature of Gannoruwa $\left(23.5^{\circ} \mathrm{C}\right)$ was more similar to that in Marassana $\left(22.5{ }^{\circ} \mathrm{C}\right)$ than Nuwara Eliya $\left(15.8^{\circ} \mathrm{C}\right)$. Considering minimum modifications to the soil environment caused by temperature conditions in the planthouse, soil collected from the vegetable cultivated field in Marassana was used for the two pot-experiments.

From the ten botanicals only eight were selected randomly (Brachiaria, cinnamon, clove, karanda, neem, nutmeg, pepper, and wild-sunflower) for the first potexperiment and all 10 botanicals were selected for the second pot-experiment considering the logistics in conducting experiments. The first pot-experiment was conducted using capsicum (Capsicum annuum L.) cultivar 'CA-8' and tomato (Solanum lycopersicum L.) cultivar 'T-246' as the test crops. Small pots (capacity of $250 \mathrm{~mL}$ ) were filled with $500 \mathrm{~g}$ of soil and uniformly grown healthy seedlings of capsicum ( $28 \mathrm{~d}$ old) and tomato (21 d old) were transplanted. The fertilizer recommendations for capsicum and tomato issued by the Department of Agriculture, Sri Lanka was practiced (Lathiff and Upali 2010). Since the plant were grown only up to $50 \%$ flowering stage only the basal-dressing at planting and the first top-dressing (tomato $-21 \mathrm{~d}$ after transplanting; capsicum $-28 \mathrm{~d}$ after transplanting) were applied. Phosphorous was applied at basal-dressing to all pots (equivalent to a rate of $44 \mathrm{~kg} \cdot \mathrm{ha}^{-1}$ ). Potassium was applied to tomato and capsicum at a rate equivalent to $16 \mathrm{~kg} \cdot \mathrm{ha}^{-1}$. application ${ }^{-1}$ and $32 \mathrm{~kg} \cdot \mathrm{ha}^{-1}$ application $^{-1}$, respectively at each fertilization event (basal-dressing and the first top-dressing). Corresponding N-rates for the two crops were equivalent to $30 \mathrm{~kg} \cdot \mathrm{ha}^{-1}$.application ${ }^{-1}$ and $45 \mathrm{~kg} \cdot \mathrm{ha}^{-1}$. application $^{-1}$, respectively at each fertilization event (basal-dressing and the first top-dressing). Urea, triple super phosphate (TSP) and murate of potash (MOP) were used as the N, P and K sources, respectively. The following $14 \mathrm{~N}$-treatments were applied; zero urea, $100 \%$ urea, $75 \%$ urea, $75 \%$ urea+DCD, $75 \%$ urea+botanical (each botanical separately as $10 \mathrm{~N}$-treatments) in three replicates. The botanicals were applied at the rate of $30 \% \mathrm{w} / \mathrm{w}$ of $\mathrm{N}$ applied from urea and DCD at $10 \mathrm{mg} \cdot \mathrm{kg}^{-1}$ soil (Gong et al. 2013) with urea to the pots at each basal-dressing and top-dressing event. In this experiment, a reduced rate of urea ( $75 \%$ from the recommendation) was used with NI to test whether applying NI could lead to reduce fertilizer $\mathrm{N}$ requirement, especially because leaching losses have not been allowed. Pots were placed in a completely randomized design (CRD) while conducting required agronomic practices as weed, pest and disease control, giving equal and sufficient space and sunlight. At each irrigation event, $50 \mathrm{~mL}$ of water was applied per pot without allowing free drainage. At $50 \%$ flowering (tomato $-30 \mathrm{~d}$ after transplanting; capsicum - $37 \mathrm{~d}$ after transplanting) plants were harvested and fresh and dry weights of the biomass were recorded.

A second pot-experiment was conducted with capsicum CA 8 variety as the test crop using soil collected from the same location as in the previous potexperiment. The same fertilizer application schedule as in the first pot-experiment was used as per the recommendation for capsicum (Lathiff and Upali 2010). Here, the following $13 \mathrm{~N}$-treatments were applied; zero urea, $100 \%$ urea, $100 \%$ urea+DCD, $100 \%$ urea+botanical (each botanical separately as $10 \mathrm{~N}$-treatments). Botanicals and DCD were applied at the rate mentioned in the first pot-experiment. In this experiment, all pots were irrigated equally ( $100 \mathrm{~mL}$ per pot) at each event and free drainage was allowed during the period of water sample collection. Leachate was collected for $\mathrm{NO}_{3}{ }^{-}$analysis at third, sixth and ninth days after fertilization. At $37 \mathrm{~d}$ after transplanting, the crop was harvested and dry matter contents were recorded. Leached water was analyzed for $\mathrm{NO}_{3}{ }^{-}$using colorimetric method proposed by Cataldo et al. (1975).

\section{Assessment of non-target effects of botanicals}

The prepared botanicals were tested for their effects on non-target organisms. Here, the effects on soil bacteria, soil fungi and seed germination of capsicum and tomato were assessed in a series of bioassays. 


\section{Assessment on non-target bacteria and fungi}

The two air dried soils from Nuwara Eliya and Marassana were remoistened to achieve 50\% (w/w) gravimetric water content. Seven days after remoistening, soils were mixed with each botanical separately $(1 \% \mathrm{w} / \mathrm{w})$ and filled into bottles (10 $\mathrm{g}$ each) in triplicates. Soil mixed with DCD (10 $\left.\mathrm{mg} \cdot \mathrm{kg}^{-1}\right)$ served as the positive control and soil only control served as the negative control. Soils were incubated at $29 \pm 1{ }^{\circ} \mathrm{C}$ for $7 \mathrm{~d}$. At the end of the incubation, soils were analyzed for the abundance of bacteria and fungi using serial dilution with spread plate technique. Tryptic Soy Agar (TSA) and Rose Bengal Agar (RBA) were used as the specific growth media to culture bacteria and fungi. Culture plates were incubated for 3 and $7 \mathrm{~d}$ before making observations for colony forming units (CFU) of bacteria and fungi, respectively.

\section{Assessment on seed germination}

The effects of botanicals on seed germination were tested in a bioassay carried out on petri-dishes lined with blotting papers in three replicates (Wardle et al. 1992). Paper in the plate was wetted with plant powder suspended in distilled water $(0.1 \% \mathrm{w} / \mathrm{v})$. A DCD $\left(10 \mathrm{mg} \cdot \mathrm{L}^{-1}\right)$ solution and distilled water in place of botanical treatment were used as the positive and negative controls, respectively. Ten seeds of tomato and capsicum were placed in each petri-dish separately and germination was observed after $7 \mathrm{~d}$.

The seed germination test was repeated on two different soils collected from Nuwara Eliya and Marassana to test the effect of botanicals on seed germination in a soil matrix. Each soil was treated with each botanical at a rate of $1 \%(\mathrm{w} / \mathrm{w})$ separately and packed into petri-dishes. DCD applied (10 $\left.\mathrm{mg} \cdot \mathrm{kg}^{-1}\right)$ and soil only plates were included as the positive and negative controls, respectively. Ten seeds of tomato and capsicum were placed in petri-dishes separately and germination was observed after $7 \mathrm{~d}$. The treatments were repeated with adding ammonium sulfate to soil at a rate of $50 \mathrm{mg} \cdot \mathrm{kg}^{-1}$ soil. In seed germination bioassays, three replicates were used.

\section{Assessment on activity of ammonia-oxidizers}

Considering the performance of botanicals in the above series of experiments, two botanicals ranking above (cinnamon and pepper) and two botanicals ranking below (karanda and neem) DCD were selected. These four botanicals were assessed for their impact on ammonia-oxidizers' activity. Two AOB isolates (M1 and NE1) having similar cell morphology (cocci) but isolated from vegetable-cultivated soils from two different agro-ecological regions were used in this bioassay. The two isolates were inoculated into A-PB medium supplemented with selected botanicals separately at two rates ( 0.1 and $\left.0.6 \mathrm{~g} \cdot \mathrm{L}^{-1}\right)$ and tested for the rate of nitrite formation. Here, $4.5 \mathrm{~mL}$ of A-PB medium, $0.5 \mathrm{ml}$ of culture grown in TSB and $0.5 \mathrm{~mL}$ of botanical suspensions (to achieve 0.1 and $0.6 \mathrm{~g} \cdot \mathrm{L}^{-1}$ botanical rate) were mixed, and incubated for $21 \mathrm{~d}$ at $30{ }^{\circ} \mathrm{C}$. Treatments with M1 and NE1 cultures only (no NI) and treatments with each botanical only (no bacterial inoculation) and a treatment with only the growth medium (no inoculant and no NI) were included as controls. All together there were 23 treatment combinations with five replicates in the study. At the end of the incubation period, the culture medium was tested for nitrite $\left(\mathrm{NO}_{2}{ }^{-}\right)$concentration colorimetrically (Schmidt and Belser 1994). The absorbance level of pinkish purple colour which developed was measured using a spectrophotometer (Jenway 6305 UV/VIS Spectrophotometer) at $440 \mathrm{~nm}$ wave length.

\section{Statistical analysis}

Data on the abundance of bacteria and fungi were log transformed to express as $\log _{10} \mathrm{CFU} \cdot \mathrm{g}^{-1}$ dry soil. Data generated from bioassays, soil incubation and pot experiments were tested for normality (Anderson Darling Test at $P$ value of 0.05 ) before using in the analysis of variance (ANOVA). The effect of botanicals on growth of nitrifiers under in-vitro condition were statistically analyzed using ANOVA and mean separation was performed using Tukey's $(P<0.05$ level) method. In soil incubation study, there were three grouping factors as soil type (two soils), sulfate of ammonia application (with and without), and N-treatment (12 treatments). Here the data analysis was performed sequentially using three-factor factorial to one-way ANOVA design. Firstly, three-way ANOVA was performed considering the three grouping factors. Since the main effect of soil type was significant, two-way ANOVA was performed considering the ammonium sulfate treatment and the effects of NItreatment and their interactions separately for each soil. Since the interaction effects were significant, one-way ANOVA was performed to test the significance of NI-treatment effect on measured parameters separately with the presence and absence of ammonium sulfate for the two soils separately. Data from the two pot-experiments were analyzed using ANOVA to study the treatment effect on biomass accumulation and $\mathrm{NO}_{3}{ }^{-}$concentration in the leachate after basal-dressing and first top-dressing. The significance of treatment effect on the abundance of bacteria and fungi was tested in ANOVA. Data were analyzed using a factorial design with ANOVA for seed germination of two crops under different test conditions. In this study, treatment means were compared using Tukey's procedure at 0.05 probability level when the treatment effect was significant. All the statistical analyses were performed using the statistical software Minitab 16 (version 4.0).

To identify the best performing botanicals from the studied materials for future experiments, data were summarized considering the performance of each as a NI with minimum non-target effect. Each botanical was quoted as good $(\mathrm{G})$, average $(\mathrm{A})$ and poor $(\mathrm{P})$ in performance compared with control in each measured 
Table 1. Characteristics of soils used for the study.

\begin{tabular}{lll}
\hline & \multicolumn{2}{l}{ Values observed $^{a}$} \\
\cline { 2 - 3 } Character with units & $\begin{array}{l}\text { Soil from } \\
\text { Nuwara Eliya }\end{array}$ & $\begin{array}{l}\text { Soil from } \\
\text { Marassana }\end{array}$ \\
\hline $\mathrm{pH}$ & $4.85 \pm 0.242$ & $6.83 \pm 0.341$ \\
$\mathrm{EC}\left(\mathrm{dS} \cdot \mathrm{m}^{-1}\right)$ & $0.16 \pm 0.008$ & $0.36 \pm 0.018$ \\
Organic C $(\%)$ & $3.36 \pm 0.168$ & $2.56 \pm 0.128$ \\
Active C $\left(\mathrm{mg} \cdot \mathrm{kg}^{-1}\right)$ & $260 \pm 13.0$ & $306 \pm 15.3$ \\
Textural class & Clay loam & Sandy loam \\
Potential nitrification rate $\left(\mathrm{mg} \mathrm{N} \cdot \mathrm{kg} \cdot \mathrm{h}^{-1}\right)$ & $0.28 \pm 0.014$ & $6.58 \pm 0.329$ \\
Ammonia-oxidizing bacteria abundance $\left(\log 10 \mathrm{cells} \cdot \mathrm{g}^{-1} \mathrm{dry} \mathrm{soil)}\right)$ & $3.36 \pm 0.168$ & $3.36 \pm 0.707$ \\
Nitrite-oxidizing bacteria abundance $\left(\log 10 \mathrm{cells} \cdot \mathrm{g}^{-1} \mathrm{dry}\right.$ soil) & $3.97 \pm 0.199$ & $2.96 \pm 0.148$ \\
Total bacteria abundance $\left(\log 10 \mathrm{CFU} \cdot \mathrm{g}^{-1} \mathrm{dry} \mathrm{soil)}\right.$ & $7.73 \pm 0.387$ & $8.44 \pm 0.422$ \\
Total fungi abundance $\left(\log 10 \mathrm{CFU} \cdot \mathrm{g}^{-1} \mathrm{dry} \mathrm{soil)}\right.$ & $3.48 \pm 0.445$ & $3.17 \pm 0.181$ \\
\hline
\end{tabular}

${ }^{a}$ Average of two replicates given as mean \pm standard deviation.

parameter in each experiment based on the results of statistical mean comparisons. Then G, A and P were assigned scores and an average score was calculated for each of the nitrification inhibition related characters (able to suppress population growth of AOB isolates, able to retard $\mathrm{NO}_{3}{ }^{-}$formation in soil, improve biomass accumulation of crops, and reduce $\mathrm{NO}_{3}{ }^{-}$leaching) and non-target effects related traits (no inhibition of seed germination and no effect on the abundance of bacteria and fungi in soil). Then total scores were calculated for nitrification inhibition and non-target effects giving equal weightage to each of the measured trait under these two categories. The overall score was calculated by using the following eqs. 1 and 2 and then the botanicals were ranked according to the performance based on the two scores.

$$
\begin{aligned}
& \mathrm{OS} 1=\left(\frac{2}{3} \mathrm{NI}\right)+\left(\frac{1}{3} \mathrm{NT}\right) \\
& \mathrm{OS} 2=\left(\frac{1}{2} \mathrm{NI}\right)+\left(\frac{1}{2} \mathrm{NT}\right)
\end{aligned}
$$

where NI = total score for nitrification inhibition potential; NT = total score for non-target effects; OS1 = overall score considering more weightage from NI; OS2 = overall score considering equal weightage from NI and NT.

\section{Results}

Characteristics of botanicals and soils used in the study

Total $\mathrm{N}$ content in botanicals ranged from $1.31 \%$ to $3.79 \%$ with the highest and the lowest values observed in leaf powders of lantana and clove, respectively (Supplementary Table S2 ${ }^{1}$; details total $\mathrm{N}$ content of the dried leaf powders (botanicals) used in the study). The soils from Marassana and Nuwara Eliya had different chemical and microbiological characteristics (Table 1).
Soil from Marassana was less acidic and had a higher PNR than the soil from Nuwara Eliya (Table 1).

\section{Effect of botanicals on population growth of nitrifiers}

All five AOB isolates used in bioassays were gramnegative. The cells of isolates M1 and NE1 were coccoid forms while other three isolates were short-rods (Fig. 1). On agar plates (A-PB medium plus $15 \mathrm{~g}$ agar $\cdot \mathrm{L}^{-1}$ ) all isolates formed circular shape translucent colonies with undulating margins in 4-5 d after inoculation. These colonies gradually turned into brownish color in about $7 \mathrm{~d}$ after their appearance.

The effectiveness of botanicals in suppressing the growth of AOB was significantly different for the three AOB isolate (Fig. 2). It was noted that addition of leaf powder at a rate of $0.01 \mathrm{~g} \cdot \mathrm{L}^{-1}$ did not cause turbidity in the growth medium. None of the botanicals could suppress the isolate M4 significantly. Only the isolate M7 was suppressed by seven out of ten botanicals. Only the leaf powders of cinnamon and nutmeg suppressed the growth of two out of three isolates significantly $(P<0.05)$.

\section{The effect of botanicals and DCD on nitrate formation in soil}

The main effects of soil type and NI-treatment were significant $(P<0.001)$ on $\mathrm{NO}_{3}{ }^{-}$content in soil. Also, the three-way interaction of the main effects (Soil type $\times$ application of sulfate of ammonia $\times$ NI-treatment) was significant $(P<0.001)$ on $\mathrm{NO}_{3}{ }^{-}$ content in soil. Hence, the data were analyzed separately for the two soils. The two-way interaction of NI-treatment and the application of sulfate of ammonia were significant in soils from Marassana and Nuwara Eliya $(P<0.001$ and $P=0.008$ respectively). In soil collected from Marassana, none of the botanicals reduced the $\mathrm{NO}_{3}{ }^{-}$formation (Table 2). When botanicals were applied together with sulfate of ammonia, only lantana reduced $\mathrm{NO}_{3}{ }^{-}$formation in soil from Nuwara Eliya (Table 2). DCD was not effective in both 
Fig. 1. Photomicrographs of five ammonia-oxidizing bacteria isolates [(A) - M1; (B) - M4; (C) - M5; (D) - M7; (E) - NE1] captured using Olympus CX41 light microscope fitted with a digital imaging camera.
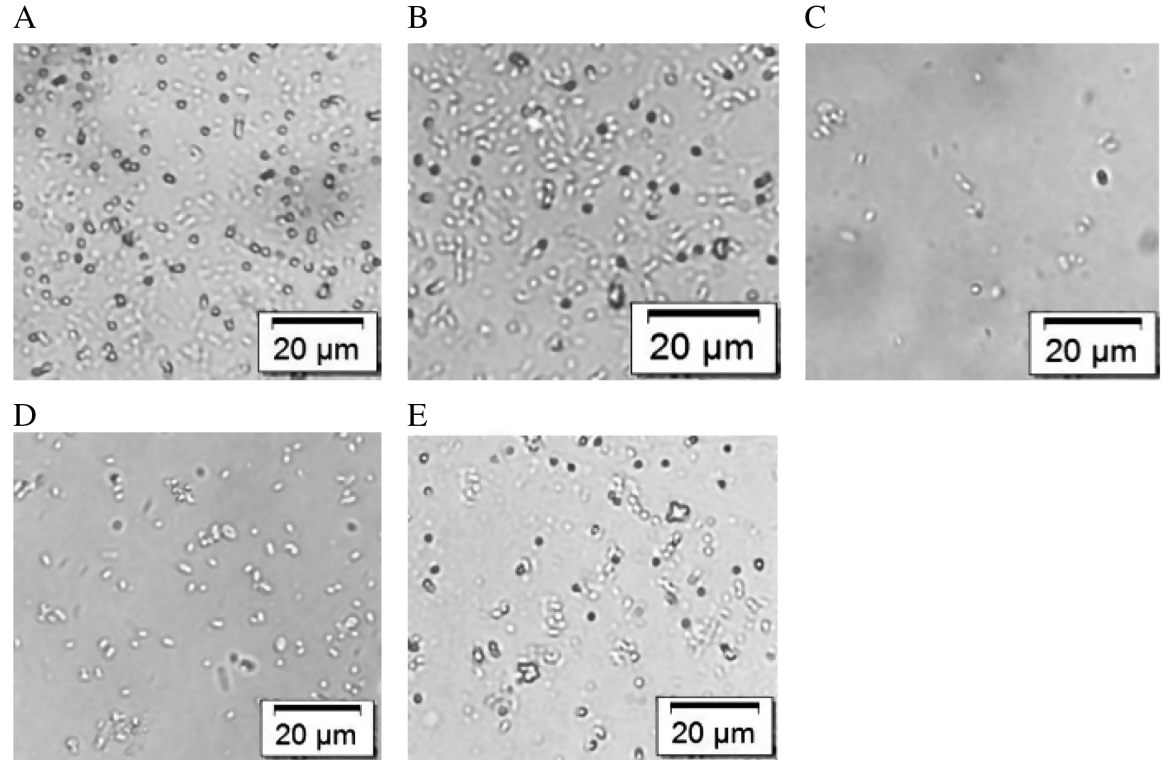

Table 2. Mean nitrate concentration $\left(\mathrm{mg} \cdot \mathrm{kg}^{-1}\right)$ in two soils from Marassana and Nuwara Eliya $2 \mathrm{~d}$ after applying $12 \mathrm{~N}$ treatments [10 botanical formulations, DCD and non-amended control with and without ammonium sulfate (SA)]

\begin{tabular}{llllll}
\hline & \multicolumn{4}{l}{ Nitrate concentration $\left(\mathrm{mg} \cdot \mathrm{kg}^{-1}\right)^{*}$} \\
\cline { 2 - 3 } & \multicolumn{2}{l}{ Soil from Marassana } & & \multicolumn{2}{l}{ Soil from Nuwara Eliya } \\
\cline { 2 - 3 } \cline { 5 - 6 } N Treatment & $-\mathrm{SA}$ & + SA & & - SA & + SA \\
\hline Control & $16.3 \pm 2.7 \mathrm{~d}$ & $45.5 \pm 16.8 \mathrm{bcd}$ & & $10.5 \pm 3.2 \mathrm{e}$ & $58.2 \pm 3.3 \mathrm{bcd}$ \\
DCD & $9.9 \pm 5.4 \mathrm{~d}$ & $42.9 \pm 2.2 \mathrm{~cd}$ & & $45.4 \pm 12.5 \mathrm{bcd}$ & $43.3 \pm 1.5 \mathrm{cde}$ \\
Brachiaria & $14.8 \pm 2.4 \mathrm{~d}$ & $44.9 \pm 8.0 \mathrm{bcd}$ & & $14.8 \pm 5.6 \mathrm{e}$ & $42.9 \pm 8.2 \mathrm{bcde}$ \\
Cinnamon & $9.0 \pm 4.8 \mathrm{~d}$ & $27.5 \pm 0.7 \mathrm{~cd}$ & & $57.1 \pm 7.8 \mathrm{bc}$ & $64.3 \pm 28.1 \mathrm{abcd}$ \\
Clove & $11.6 \pm 3.3 \mathrm{~d}$ & $25.9 \pm 6.4 \mathrm{~cd}$ & & $27.5 \pm 7.2 \mathrm{cde}$ & $63.0 \pm 18.4 \mathrm{bcd}$ \\
Karanda & $36.5 \pm 6.4 \mathrm{bc}$ & $79.4 \pm 11.2 \mathrm{a}$ & & $92.9 \pm 3.4 \mathrm{a}$ & $101.6 \pm 20.2 \mathrm{ab}$ \\
Lantana & $34.9 \pm 4.8 \mathrm{bc}$ & $40.2 \pm 5.1 \mathrm{~cd}$ & & $9.5 \pm 2.2 \mathrm{e}$ & $<0.1 \mathrm{e}$ \\
Mee & $14.3 \pm 0.0 \mathrm{~cd}$ & $10.6 \pm 1.8 \mathrm{~d}$ & & $75.4 \pm 1.1 \mathrm{ab}$ & $66.7 \pm 2.2 \mathrm{~b}$ \\
Neem & $61.9 \pm 11.1 \mathrm{a}$ & $33.3 \pm 7.3 \mathrm{~cd}$ & & $66.1 \pm 13.1 \mathrm{ab}$ & $120.6 \pm 34.4 \mathrm{a}$ \\
Nutmeg & $1.1 \pm 1.8 \mathrm{~d}$ & $55.1 \pm 7.3 \mathrm{abc}$ & & $21.4 \pm 12.3 \mathrm{de}$ & $11.5 \pm 7.8 \mathrm{de}$ \\
Pepper & $40.5 \pm 5.6 \mathrm{~b}$ & $72.4 \pm 18.7 \mathrm{ab}$ & & $18.3 \pm 4.0 \mathrm{de}$ & $33.3 \pm 4.2 \mathrm{cde}$ \\
Wild-sunflower & $38.6 \pm 3.3 \mathrm{~b}$ & $31.7 \pm 9.0 \mathrm{~cd}$ & & $65.1 \pm 13.7 \mathrm{ab}$ & $79.4 \pm 42.7 \mathrm{abc}$ \\
\hline P value & $<0.001$ & $<0.001$ & $<0.001$ & $<0.001$ \\
\hline
\end{tabular}

Note: Values are indicated as means \pm standard deviation. Means followed by the same letter in a given column are not significantly different at $P>0.05$.

${ }^{*}$ Concentrations below detection limit of the technique used are indicated as $<0.1 \mathrm{mg} \cdot \mathrm{kg}^{-1}$. Significance of treatment effect is given as $P$ value.

soils in reducing $\mathrm{NO}_{3}{ }^{-}$formation (Table 2). The total $\mathrm{N}$ content of botanical and the $\mathrm{NO}_{3}{ }^{-}$concentration in soil did not have a significant correlation $(P>0.05)$.

\section{Effect of botanicals on biomass accumulation of tomato and capsicum}

Treatment effects were significant on the biomass accumulation of both crops in the first pot-experiment, in which, plants were grown without allowing free drainage (Fig. 3). There the biomass of capsicum was increasing significantly with 75\% urea (N75) and 100\% urea (N100) compared with zero-urea (N0) but not the biomass of tomato (Fig. 3). But that effect was not observed in capsicum when allowing free drainage (Fig. 4). There was a decrease in dry biomass of capsicum with N75+karanda compared with N75 while for tomato 
Fig. 2. Optical density of growth medium measured at $600 \mathrm{~nm}$ wave-length depicting the population growth of three ammoniaoxidizing bacteria isolates (M4, M5, and M7) as affected by DCD and 10 botanicals in a laboratory bioassay. Bacteria without any amendment served as the control. Means followed by the same letter are not significantly different $(P>0.05)$. Error bars represent standard deviation. Significance of treatment effect is indicated as $P$ value.
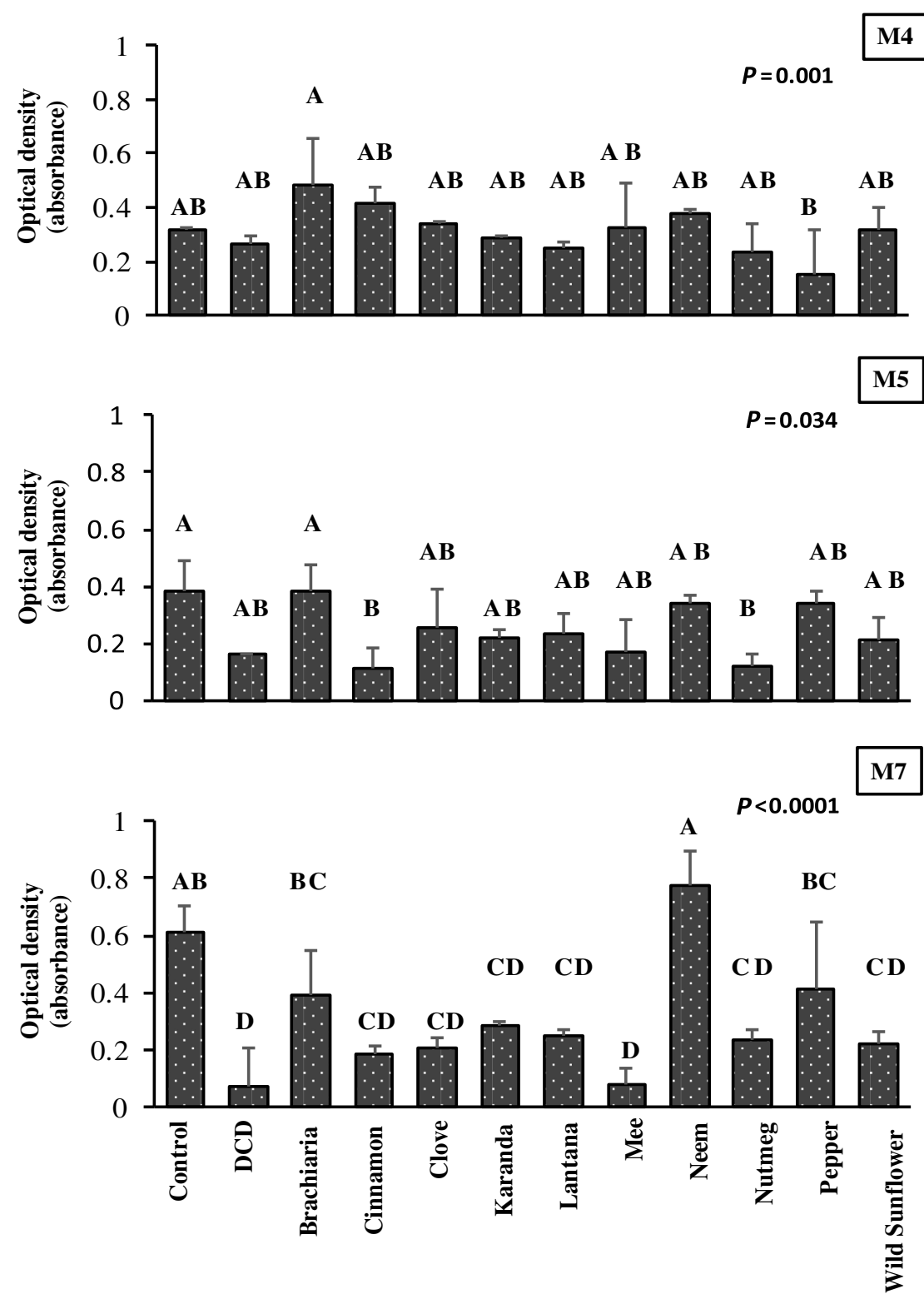

N75+pepper increased dry biomass compared with N75 when plants were grown without allowing free drainage (Fig. 3). Although the dry biomass of capsicum shoots was not increasing with N100 compared with N0, the application of $\mathrm{N} 100+$ mee, N100+nutmeg and $\mathrm{N} 100+$ wild-sunflower resulted in increasing biomass compared with NO when allowing free drainage (Fig. 4). A notable reduction in shoot dry biomass of capsicum plants were observed when free drainage was allowed (Figs. 3 and 4). The application of fertilizer- $\mathrm{N}$ significantly enhanced $(P<0.05) \mathrm{NO}_{3}{ }^{-}$leached from soil at both fertilization events (Table 3 ). Although the application of DCD reduced the magnitude of $\mathrm{NO}_{3}{ }^{-}$leached from soil it is not statistically significant $(P>0.05)$. However, applying eight out of ten botanicals together with $\mathrm{N}$-fertilizer significantly $(P<0.05)$ reduced $\mathrm{NO}_{3}{ }^{-}$leached from soil after basal-dressing (Table 3 ). The $\mathrm{NO}_{3}{ }^{-}$level in leachate did not have a significant correlation $(P>0.05)$ with the mean shoot dry weight of capsicum.

\section{The non-target effects of the botanicals}

The treatment effect was not significant $(P>0.05)$ on the abundance of either bacterial or fungal populations (data not shown). The seed germination was significantly affected $(P<0.05)$ by the botanicals in both bioassays 
Fig. 3. Average dry biomass of shoots of tomato and capsicum plants at flower initiation stage under $\mathrm{N}$ treatments ( $\mathrm{N}$ fertilizer at $0 \%, 75 \%$ and $100 \%$ rates and DCD and eight botanicals applied along with $75 \%$ of $\mathrm{N}$ fertilizer) when free drainage from pots were not allowed. Means followed by the same letter are not significantly different $(P>0.05)$. Error bars represent standard deviation. Significance of treatment effect is indicated as $P$ value.
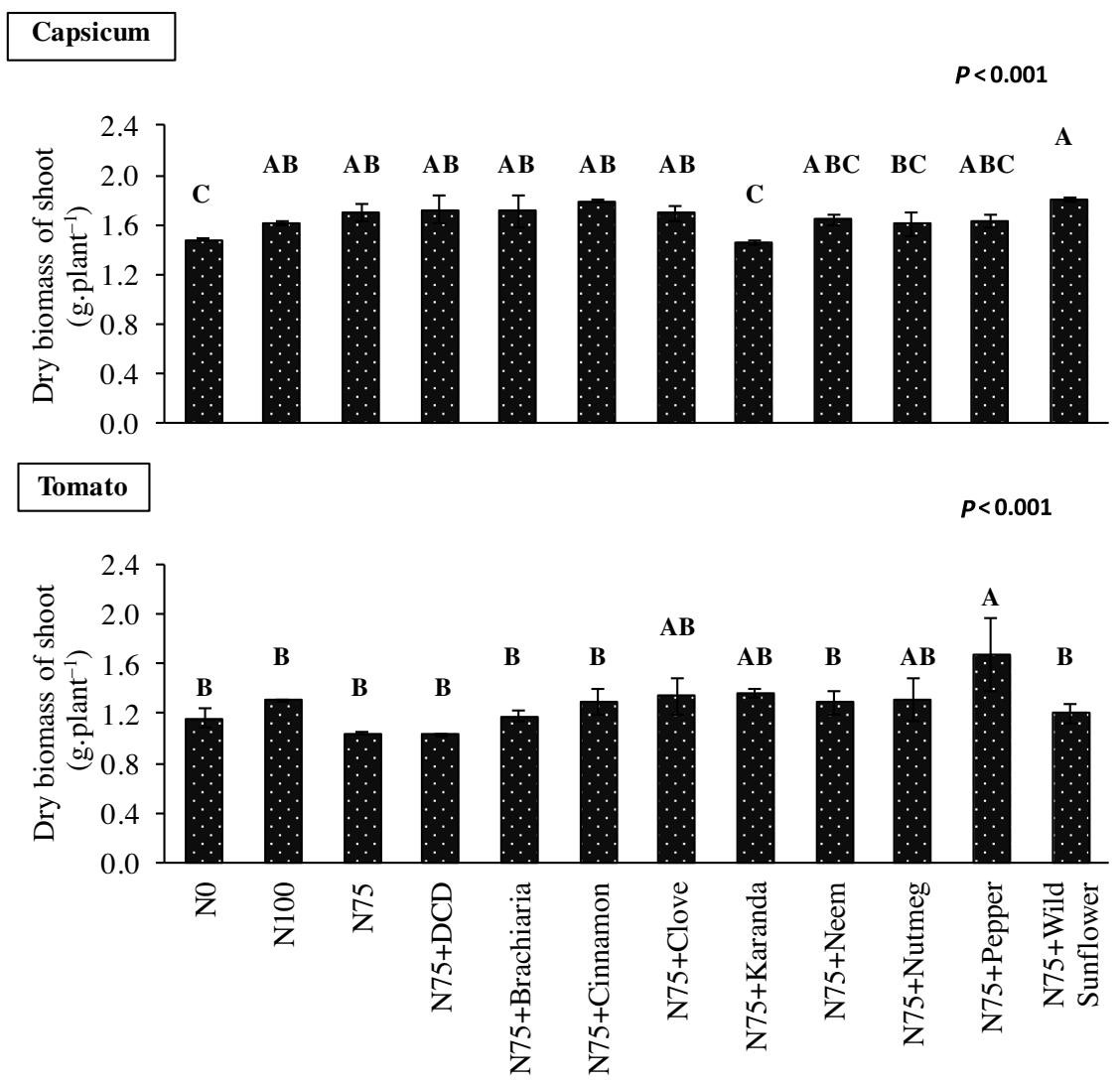

conducted without and with soil (Figs. 5 and 6). However, the results of seed germination on soil were different from the pattern observed with germination on blotting paper (Figs. 5 and 6). The application of clove consistently and significantly reduced seed germination in all related bioassays. Except for cinnamon and neem all other eight botanicals suppressed seed germination on blotting papers for both crops (Fig. 5). Except for cinnamon all other botanicals suppressed seed germination in at least one soil when fertilizer-N was not applied (Fig. 6). Applying botanicals along with N-fertilizer improved seed germination compared with applying botanicals alone in soil from Nuwara Eliya only. The interaction effect between application of $\mathrm{N}$-fertilizer and soil type was significant $(P<0.05)$ on seed germination.

\section{Identifying the overall best botanicals}

The performance of tested botanicals in each experiment was summarized to identify the most suitable materials to continue for future studies to develop botanical NI. The summary is presented in Table 4 . According to the overall score calculated using eqs. 1 and 2 and respective ranking of the botanicals, leaf powders of pepper, mee, lantana, cinnamon, and nutmeg ranked as the top five materials (Table 4). Analysis of two botanicals from this list (cinnamon and pepper) and two ranked lower than DCD (neem and karanda) on their effectiveness in suppressing the activity of two AOB isolates confirmed that they could suppress ammonia-oxidation (Fig. 7). The activity of isolate M1 was suppressed by all four botanicals but AOB isolate NE1 was suppressed by only cinnamon and karanda at $0.1 \mathrm{~g} \cdot \mathrm{L}^{-1}$ concentration and pepper at $0.6 \mathrm{~g} \cdot \mathrm{L}^{-1}$ concentration (Fig. 7). Results confirmed that the botanicals of cinnamon, pepper, and karanda are better than neem as NIs. The estimated nitrite formation rates for M1 and NE1 isolates were approximately 0.8 and 1.3 million $\mathrm{g}$ $\mathrm{N} \cdot$ day $^{-1} \cdot \mathrm{g}^{-1}$ dry cells, respectively.

\section{Discussion}

Differences in the diversity of nitrifiers

In the present study, although soils collected from Marassana and Nuwara Eliya had ammonia-oxidizers in similar abundance the PNR of the former was nearly 23 folds higher than the latter (Table 1). Further, unlike 
Fig. 4. Average dry biomass of shoots of capsicum plants at flower initiation stage under $\mathrm{N}$-treatments ( $\mathrm{N}$ fertilizer at $0 \%$ and $100 \%$ rates and DCD and ten botanicals applied along with $100 \%$ of $\mathrm{N}$ fertilizer) when free drainage from pots were allowed. Means followed by the same letter are not significantly different $(P>0.05)$. Error bars represent standard deviation. Significance of treatment effect is indicated as $P$ value.

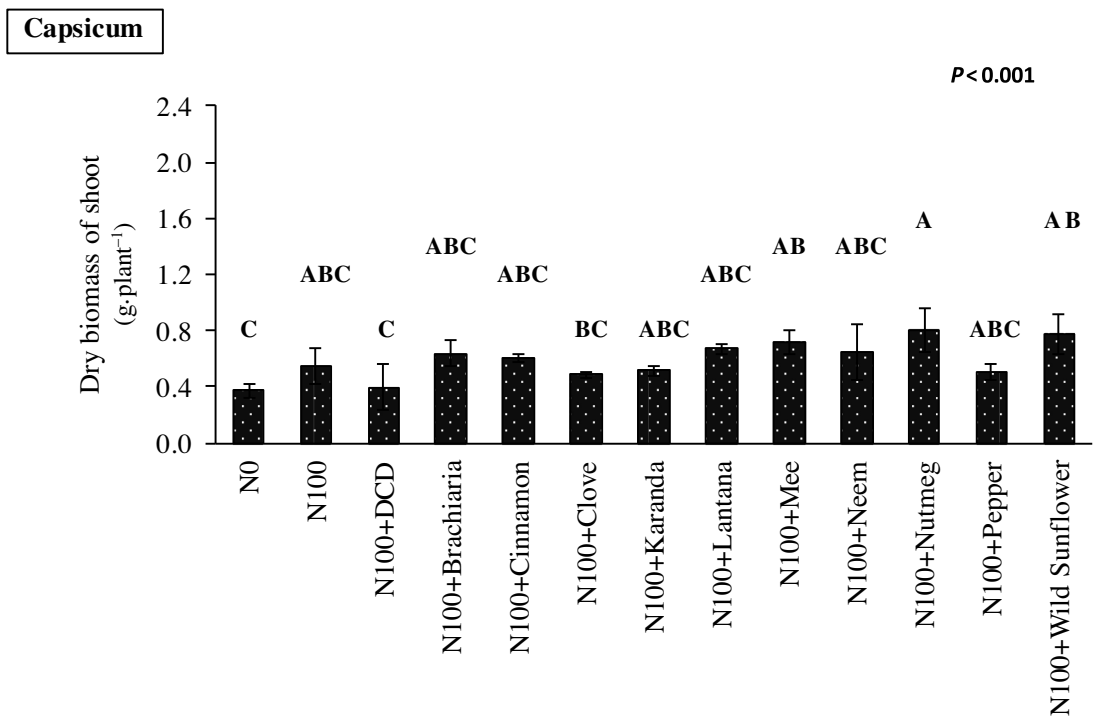

Table 3. The average concentration of $\mathrm{NO}_{3}{ }^{-}-\mathrm{N}$ in leachate during $9 \mathrm{~d}$ after fertilization at basal-dressing and top-dressing for capsicum grown under thirteen different $\mathrm{N}$ treatments $(\mathrm{N}$ fertilizer at $0 \%$ and $100 \%$ rates and DCD and 10 botanicals applied along with $100 \%$ of $\mathrm{N}$ fertilizer) allowing free drainage from pots.

\begin{tabular}{lll}
\hline & \multicolumn{2}{l}{$\begin{array}{l}\text { Mean } \mathrm{NO}_{3}{ }^{-}-\mathrm{N} \text { in leachate after } \\
\text { fertilization }\left(\mu \mathrm{g} \cdot \mathrm{ml}^{-1}\right)\end{array}$} \\
\cline { 2 - 3 } & $\begin{array}{l}\text { At basal- } \\
\text { dressing }\end{array}$ & $\begin{array}{l}\text { At first top-dressing } \\
\left(\mu \mathrm{g} \cdot \mathrm{ml}^{-1}\right)\end{array}$ \\
\hline Treatment & $2.3 \pm 1.75 \mathrm{c}$ & $3.5 \pm 2.28 \mathrm{~b}$ \\
Control 1 - 0\% urea & $8.1 \pm 1.34 \mathrm{a}$ & $7.1 \pm 2.74 \mathrm{a}$ \\
Control 2 - 100\% urea & $5.4 \pm 3.23 \mathrm{abc}$ & $5.9 \pm 1.73 \mathrm{ab}$ \\
$100 \%$ urea + DCD & $4.6 \pm 2.99 \mathrm{bc}$ & $5.7 \pm 4.22 \mathrm{ab}$ \\
$100 \%$ urea + Brachiaria & $4.2 \pm 2.89 \mathrm{bc}$ & $6.9 \pm 3.82 \mathrm{a}$ \\
$100 \%$ urea + cinnamon & $5.9 \pm 4.17 \mathrm{abc}$ & $6.8 \pm 2.69 \mathrm{ab}$ \\
$100 \%$ urea + Clove & $2.7 \pm 0.92 \mathrm{c}$ & $6.5 \pm 2.59 \mathrm{ab}$ \\
$100 \%$ urea + Lantana & $5.3 \pm 1.13 \mathrm{bc}$ & $5.7 \pm 0.98 \mathrm{ab}$ \\
$100 \%$ urea + Mee & $5.6 \pm 1.40 \mathrm{bc}$ & $5.3 \pm 2.18 \mathrm{ab}$ \\
$100 \%$ urea + Neem & $4.5 \pm 2.37 \mathrm{bc}$ & $6.8 \pm 2.73 \mathrm{ab}$ \\
$100 \%$ urea + Nutmeg & $3.3 \pm 1.54 \mathrm{c}$ & $6.8 \pm 2.96 \mathrm{ab}$ \\
$100 \%$ urea + Pepper & $2.5 \pm 1.47 \mathrm{c}$ & $6.9 \pm 3.22 \mathrm{ab}$ \\
$100 \%$ urea + Wild sunflower & $7.4 \pm 3.94 \mathrm{abc}$ & $5.9 \pm 2.80 \mathrm{ab}$ \\
\hline P value & 0.043 & 0.043 \\
\hline
\end{tabular}

Note: Means followed by the same letter given in a column are not significantly different at $P>0.05$. Values are indicated as mean \pm standard deviation.

the clayey acidic soil from Nuwara Eliya, the soil from Marassana had sandy loam texture with $\mathrm{pH}$ closer to neutral range (Table 1). Low clay content and neutral $\mathrm{pH}$ favor high abundance and activity of AOB (Prosser and Nicol 2012; Volpi et al. 2017). On the other hand, AOA tend to dominate nitrifying communities in acidic soils 
Fig. 5. Average germination percentage of capsicum and tomato seeds as affected by nitrification inhibition (NI) treatment when testing seed germination on blotting papers. Means followed by the same letter of similar case for a given crop are not significantly different $(P>0.05)$. Error bars represent standard deviation. CV\%, coefficient of variation as a percentage; $R^{2}$-sq, goodness of fit of model used in ANOVA.

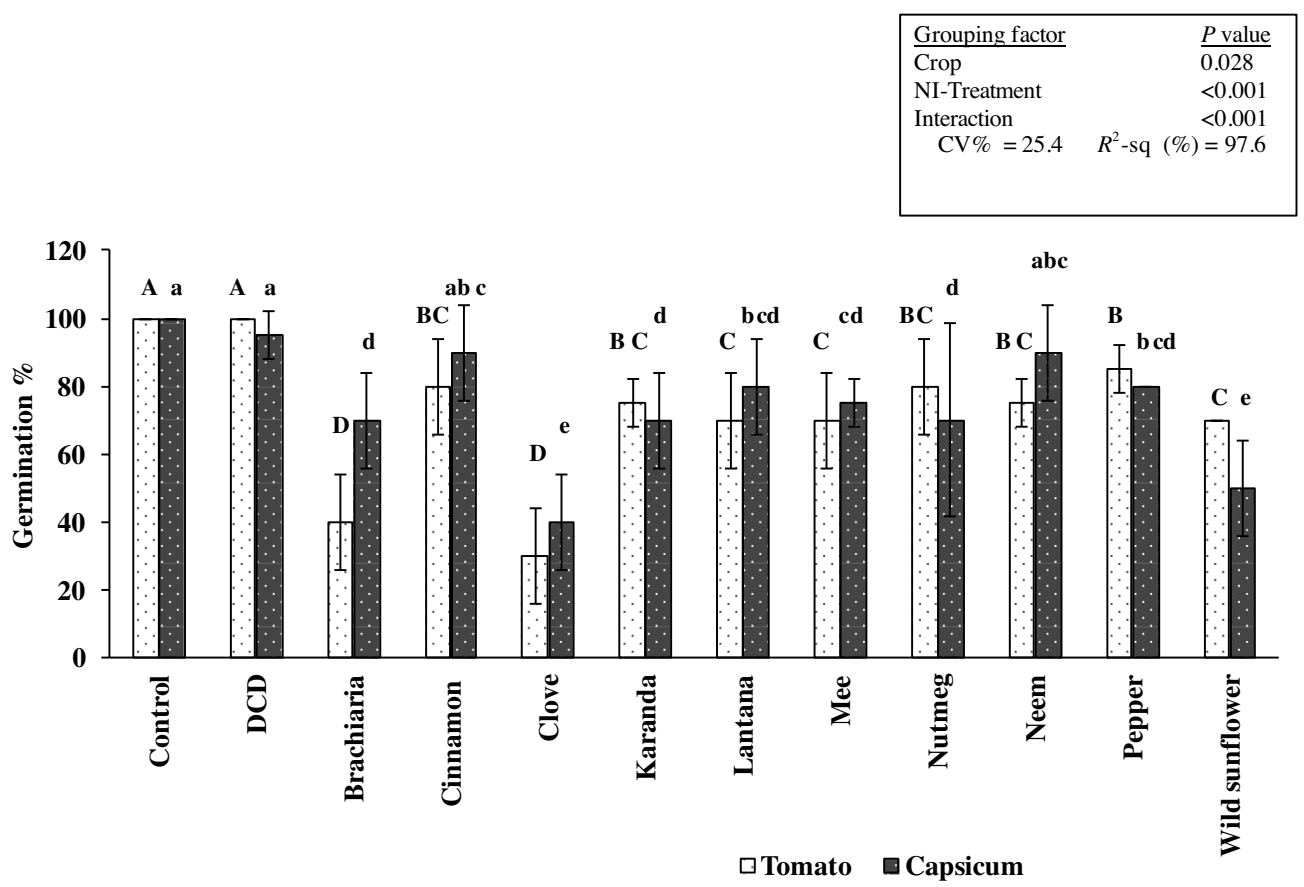

with $\mathrm{pH}$ below 5.5 (Prosser and Nicol 2012). In addition, the history of soil management, soil texture, temperature and moisture availability also affect the species composition of nitrifiers (Bollmann et al. 2002; Di and Cameron 2004; Prosser and Nicol 2012; Muema et al. 2015; Volpi et al. 2017). Ammonia-oxidizers in soils exhibit high niche specialization (Bollmann et al. 2002; Prosser and Nicol 2012). A recent study conducted in Sri Lanka indicated that PNR of soils does not correlate with the abundance of nitrifying bacteria, thus, suggesting high variability in diversity of nitrifying populations in different vegetable cultivated soils they studied (Nawarathna, et al. 2019). Therefore, the ammoniaoxidizer community composition should be different between the soils from Marassana and Nuwara Eliya.

\section{The performance of botanicals in bioassays}

In the present study, the AOB isolates, which had similar cell morphology and isolated from vegetable cultivated soils in Marassana region, were differently suppressed by the botanicals (Fig. 2). The activity of another two isolates (M1 and NE1) having coccoid shape cells were also suppressed differently by the botanicals (Fig. 7). Therefore, the AOB isolates used in this study might belong to different taxonomic groups. Rods, coccoid forms and true cocci shape cells have been reported in different species of Nitrosomonas, a common AOB found in soils (Koops et al. 1991). Nitrosospira, which is another dominant $\mathrm{AOB}$ in soil is reported to have short spiral like cells that might appear as short-rods under light microscope (Tomiyama et al. 2001).

The isolates used in the present study were obtained from soil following procedures specific for culturing lithoautotrophic bacteria. The estimated nitrite formation rate match with the range observed for lithoautotrophic ammonia-oxidizers (Krümmel and Harms 1982). Although Nitrosomonas and Nitrosospira are obligatory lithoautotrophic AOB, an increase in their growth in the presence of simple sugars has been observed previously (Krümmel and Harms 1982). Therefore, AOB may be responding to dissolved $C$ added to the media from the plant powders. From the tested botanicals Brachiaria, cinnamon, clove, karanda, lantana, mee, nutmeg, and wild-sunflower were capable of suppressing the growth of at least one AOB isolate tested (Fig. 2). Chemical compounds that inhibit the growth of Nitrosomonas europaea have been isolated from Brachiaria humidicola and karanda (known as "karanji" in India) previously (Gopalakrishnan et al. 2007; Majumdar 2002; Subbarao et al. 2013).

The performance of botanicals applied to soil

As expected $\mathrm{NO}_{3}{ }^{-}$production in soil increased with the application of $\left(\mathrm{NH}_{4}\right)_{2} \mathrm{SO}_{4}$ because $\mathrm{NH}_{4}{ }^{+}$supply is the major rate limiting factor for nitrification process (Bollmann et al. 2002). The effect of the botanicals and DCD applied to soil on $\mathrm{NO}_{3}{ }^{-}$formation was not consistent in the two soils tested. A significant reduction in 
Fig. 6. Average germination percentage of capsicum seeds in two soils applied with nitrification inhibition (NI) treatment with and without ammonium sulfate (SA). Means followed by the same letter of similar case for a given SA treatment of a soil are not significantly different $(P>0.05)$. Error bars represent standard deviation. CV\%, coefficient of variation as a percentage; $R^{2}$-sq, goodness of fit of model used in ANOVA. All two-way and three-way interactions were significant at $P<0.001$.

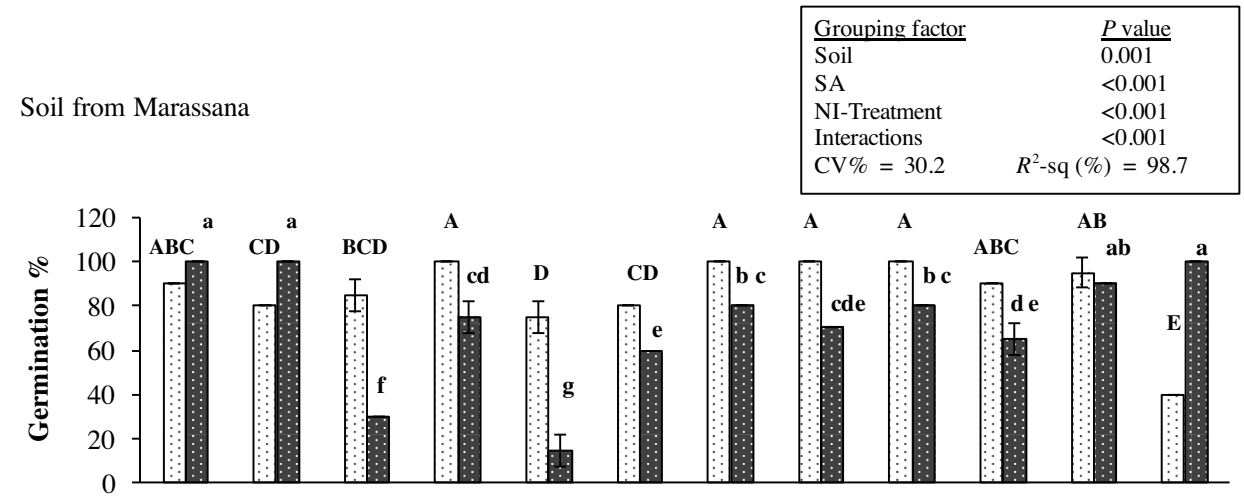

Soil from Nuwara Eliya

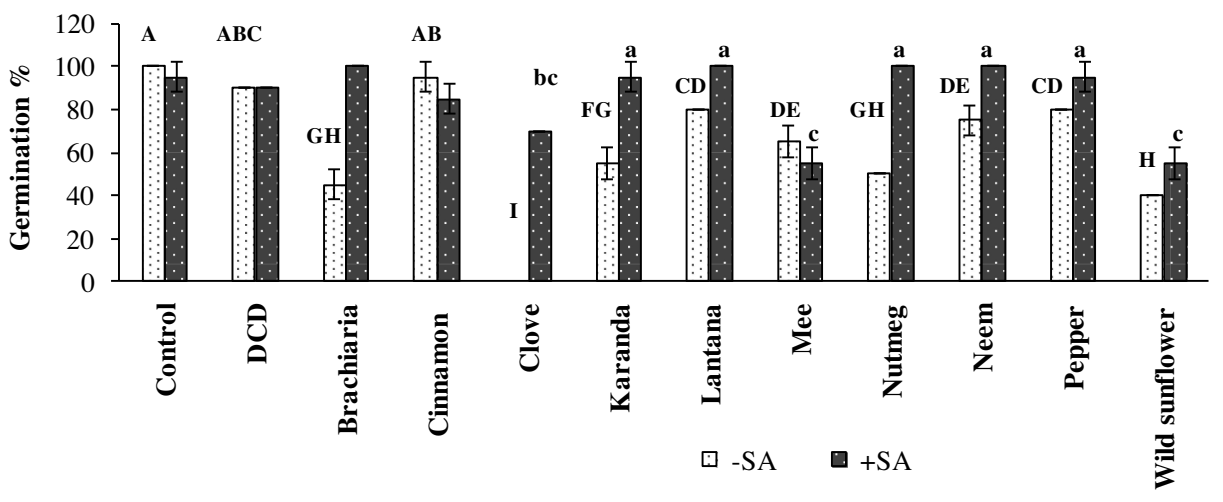

nitrate formation with the application of NI was observed only when the botanical lantana was applied to the soil from Nuwara Eliya. Reduction in $\mathrm{NO}_{3}{ }^{-}$formation in soil when lantana leaf powder is added to soil with $\mathrm{N}$-fertilizers has been reported previously (Sivasakthy and Gnanavelrajah 2012). Even though different products developed based on neem, karanda, mee, and Brachiaria suppressed the activity of AOB in previous studies (Prasad et al. 1989; Gopalakrishnan et al. 2007; Kumar et al. 2007; Subbarao et al. 2013), leaf powders from these plants did not reduce $\mathrm{NO}_{3}{ }^{-}$formation in the two soils we studied. In previous research, mee, neem, and karanda-based products have been mostly obtained from seed cake and oils (Prasad et al. 1989; Kumar et al. 2007; Subbarao et al. 2013); whereas, root-exudates have been used for Brachiaria (Gopalakrishnan et al. 2007). Kumar et al., (2007) revealed that the concentration of active ingredient responsible for suppressing nitrifiers (e.g. meliacin in neem oils) directly influence the effectiveness of the botanical as an inhibitor.

Soils that have similar organic carbon content could have significantly different mineralizable $\mathrm{N}$ contents due to differences in the quality of organic C (Spargo et al. 2011). Further, the botanical formulations developed with organic materials are mineralized by soil microorganisms (Jatana et al. 2020). Although we did not observe a significant relationship between $\mathrm{N}$ content of the botanicals and the $\mathrm{NO}_{3}{ }^{-}$levels observed in soil, with the application of some botanicals without and with $\mathrm{N}$-fertilizer $\mathrm{NO}_{3}{ }^{-}$formed in soil has increased. This may be partly due to the positive priming of $\mathrm{N}$ mineralization of native organic matter in soil by the added botanical.

Only capsicum but not tomato crop was responsive to added N-fertilizers in the first pot-experiment conducted without allowing free drainage. But applying pepper leaf powder along with $75 \%$ of $\mathrm{N}$-fertilizers significantly increased plant biomass of tomato compared $75 \%$ $\mathrm{N}$-fertilizer treatments (Fig. 3). According to a previous study, tomato cultivar 'T246' accumulated more biomass when $\mathrm{N}$ was supplied as $\mathrm{NO}_{3}{ }^{-}$whereas biomass accumulation of capsicum cultivar ' $\mathrm{CA} 8$ ' was insensitive to $\mathrm{NH}_{4}{ }^{+}: \mathrm{NO}_{3}{ }^{-}$ratio (Nawarathne et al. 2021). Further they observed that $\mathrm{N}$ and $\mathrm{K}$ content in capsicum shoots improved with more $\mathrm{NH}_{4}{ }^{+}$in the growth medium. Even a crop which prefer $\mathrm{NO}_{3}{ }^{-}$could get benefit from input 
Table 4. Summary of the performance of botanicals and DCD based on their effectiveness as nitrification inhibitors (NI) and absence of non-target effects (NT) and the calculation of overall score (OS) for ranking the materials.

\begin{tabular}{|c|c|c|c|c|c|c|c|c|c|}
\hline \multirow[b]{2}{*}{ Material } & \multicolumn{4}{|c|}{ Score for $\mathrm{NI}^{a}$} & \multicolumn{3}{|c|}{ Score for $\mathrm{NT}^{b}$} & \multicolumn{2}{|c|}{$\begin{array}{c}\text { Rank based on } \\
\text { OS }^{c}\end{array}$} \\
\hline & NI-1 & NI-2 & NI-3 & NI-4 & NT-1 & NT-2 & NT-3 & OS1 & OS2 \\
\hline DCD & 2.3 & 1.8 & 2.0 & 2.0 & 3.0 & 3.0 & 3.0 & $\mathbf{6}(8.39)$ & $\mathbf{5}(8.54)$ \\
\hline Brachiaria & 1.3 & 2.3 & 2.0 & 2.5 & 1.7 & 3.0 & 3.0 & $9(7.94)$ & $8(7.88)$ \\
\hline Cinnamon & 2.7 & 1.8 & 2.0 & 2.5 & 2.7 & 3.0 & 3.0 & $3(8.83)$ & 3 (8.79) \\
\hline Clove & 2.3 & 2.0 & 2.0 & 2.0 & 1.3 & 3.0 & 3.0 & $8(8.00)$ & $10(7.83)$ \\
\hline Karanda & 2.3 & 1.3 & 1.7 & 2.5 & 2.0 & 3.0 & 3.0 & $10(7.83)$ & $8(7.88)$ \\
\hline Lantana & 2.3 & 2.3 & 2.0 & 2.5 & 2.3 & 3.0 & 3.0 & $3(8.83)$ & $4(8.71)$ \\
\hline Mee & 2.3 & 1.8 & 3.0 & 2.5 & 2.2 & 3.0 & 3.0 & $1(9.11)$ & $1(8.88)$ \\
\hline Neem & 2.0 & 1.3 & 2.0 & 2.5 & 1.7 & 3.0 & 3.0 & $11(7.72)$ & $11(7.71)$ \\
\hline Nutmeg & 2.7 & 2.0 & 2.3 & 2.5 & 2.2 & 3.0 & 3.0 & $2(9.06)$ & $2(8.83)$ \\
\hline Pepper & 2.0 & 1.8 & 2.3 & 2.5 & 2.5 & 3.0 & 3.0 & $5(8.56)$ & $5(8.54)$ \\
\hline $\begin{array}{l}\text { Wild- } \\
\text { sunflower }\end{array}$ & 2.3 & 1.5 & 2.7 & 2.0 & 1.5 & 3.0 & 3.0 & $7(8.17)$ & $7(8.00)$ \\
\hline
\end{tabular}

Note: Cells coded light-grey, dark-grey, and black indicate good, average, and poor performance compared with control.

${ }^{a} \mathrm{NI}-1$, ability to suppress population growth of AOB isolates; NI-2, ability to retard nitrate formation in soil; NI-3, ability to improve biomass accumulation of crops; NI-4, ability to reduce nitrate leaching.

${ }^{b}$ NT-1, no inhibition of seed germination; NT-2 and NT-3, absence of negative effect on the abundance of bacteria and fungi in soil, respectively.

${ }^{c}$ Values within parenthesis indicated the overall score calculated. OS1 and OS2 were calculated as per the eqs. 1 and 2.

of NI to a system because NIs supports to reduce N losses prolonging $\mathrm{N}$ availability in soil (Volpi et al. 2017). In addition, a significant increase in $\mathrm{NO}_{3}{ }^{-}$formation with the application of some botanicals including pepper without a N-fertilizer to soil from Marassana was observed during the soil incubation experiment (Table 2). Therefore, these botanicals may have affected $\mathrm{N}$ mineralization in soil releasing more nutrients to the root environment of the crop. Since only pepper leaf powder lead to a significant biomass improvement of tomato, it would be worth to study the rhizosphere interaction in future.

When comparing the growth of capsicum crop in the two pot-experiments, a notable reduction (nearly 50\%) in dry biomass accumulation was observed when free drainage was allowed (Figs. 3 and 4). It should be noted that plants received $25 \%$ more $\mathrm{N}$-fertilizer in the experiment that allowed free-drainage. The two pot-experiments were conducted with overlapping in timing in the same plant house. Therefore, the differences in biomass accumulation may be due to the reduction in nutrient availability for the crop as a result of leaching losses. After both basal-dressing and top-dressing of fertilizers, $\mathrm{NO}_{3}{ }^{-}$was present in the leachate. Although the application of some NIs significantly reduced $\mathrm{NO}_{3}{ }^{-}$in the leached water after basal-dressing such a trend was not seen at top-dressing. At the time of top-dressing the 
Fig. 7. Ammonia oxidation activity of two ammoniaoxidizing bacteria isolates (NE1 and M1) obtained from soils as indicated by the nitrite concentration in the growth medium after incubating for $21 \mathrm{~d}$ with selected botanicals (cinnamon, karanda, neem, and pepper) at two concentrations $\left(0.1\right.$ and $\left.0.6 \mathrm{~g} \cdot \mathrm{L}^{-1}\right)$ in comparison to unamended control (bacterial culture alone). Means followed by the same letter are not significantly different $(P>0.05)$. Error bars represent standard deviation.
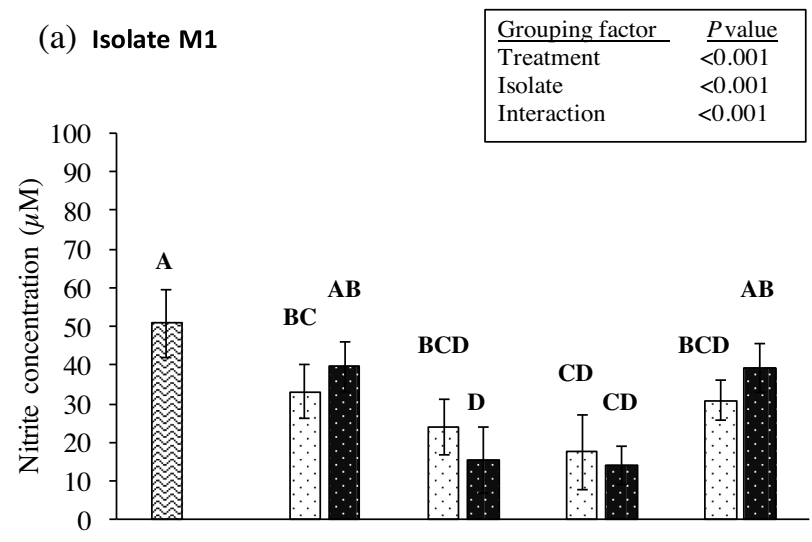

(b) Isolate NE1

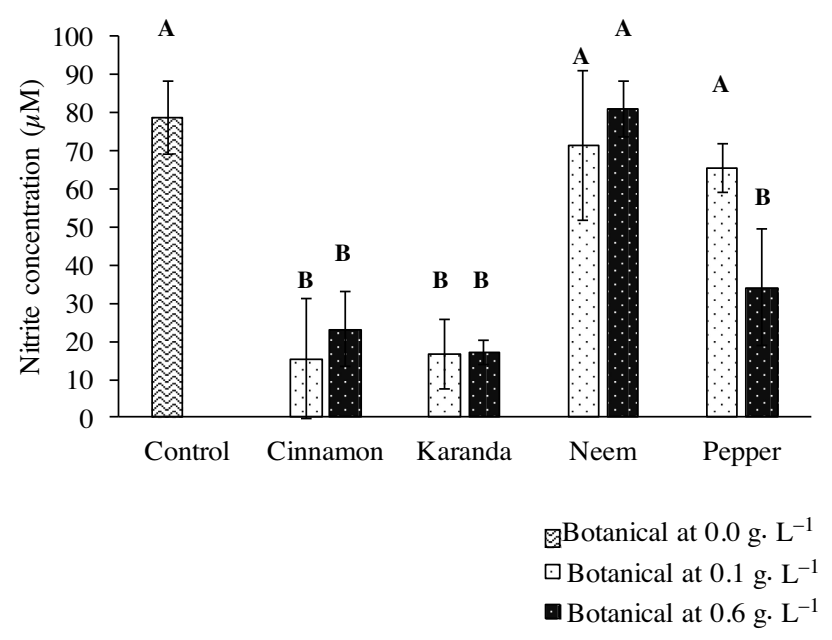

plants were well established in the pots and may be better at acquisition of nutrients from the soil. Therefore, plant-soil-microbial interactions may have partly contributed to the observation of not having a significant treatment effect on $\mathrm{NO}_{3}{ }^{-}$concentration in the leachate after top-dressing.

It is interesting to note that the application of DCD along with $\mathrm{N}$-fertilizer resulted in similar or lesser yield compared with that under $\mathrm{N}$ fertilizer alone treatment (Figs. 3 and 4). Therefore, DCD application to the crop grown in soil from Marassana did not yield a significant advantage. The DCD rate used in the pot-experiment is equivalent to $20 \mathrm{~kg} \cdot \mathrm{ha}^{-1}$. Di and Cameron (2004) applied DCD at the rates of 7.5 and $15 \mathrm{~kg} \cdot \mathrm{ha}^{-1}$ to a grazed pasture soil in New Zealand and observed that DCD prolonged the half-life of $\mathrm{NH}_{4}{ }^{+}$and increasing the rate had only a small effect. Further they reported that the half-life of DCD in soil and its effectiveness on inhibiting nitrification is high under soil temperatures below $10{ }^{\circ} \mathrm{C} \mathrm{com-}$ pared with that above $20{ }^{\circ} \mathrm{C}$.

In general, although DCD and some botanical NIs were successful in inhibiting growth and activity of AOB in bioassays, the same performance could not be seen on plant growth when these were applied to soil. Complexity of ammonia-oxidizing community that include AOA in soils may be one reason for this disparity. For instance, DCD is proven to be effective in suppressing the activity of AOB but not AOA (Gong et al. 2013). Differences in the consistency of NIs in suppressing growth and activity of AOB isolates was observed even in the present study (Figs. 2 and 7). Botanical formulations will be degraded in soil by microorganisms, and also will undergo different adsorptiondesorption kinetics depending on soil properties affecting their effectiveness in soil environment (Rawat et al. 2017). Therefore, depending on soil conditions, especially texture and $\mathrm{pH}$, differences in effectiveness of DCD as well as other NIs in suppressing nitrification also could be expected (Volpi et al. 2017).

Considering the results on $\mathrm{NO}_{3}{ }^{-}$formation in soil incubation study and $\mathrm{NO}_{3}{ }^{-}$leached in the second pot-experiment, there seems to be an effect of source of $\mathrm{N}$ (we used sulfate of ammonia and urea, respectively) on the performance of NIs, which need to be further investigated. In the pot-experiment, the results could be a collective effect of urease inhibition and nitrification inhibition. The bioassays confirmed the ammoniaoxidation inhibition property of some botanicals but it would be worth to study their urease inhibition properties as well. Although neem has been shown to have compounds with nitrification inhibition and urease inhibition properties (Kumar et al. 2007; Tanaka et al. 2010), it was not very effective compared with all other botanicals tested in the present study (Table 4).

\section{Non-target effects}

Botanical formulations have been used as insecticides for many decades and non-target effects of neembased formulations have been documented (review by Boonsoong and Bullangpoti 2009). Irrespective of the benefits that botanical formulations may have on suppressing nitrification, it is crucial to test such materials for non-target effects (Boonsoong and Bullangpoti 2009; Jatana et al. 2020). Jatana et al. (2020) reported that NIs formulated with neem cake and karanja cake had less negative effects on soil respiration, potential enzymatic activity, $\mathrm{P}$ mineralization, and microbial abundance. In our study, although the abundance of bacteria and fungi were not affected by the botanicals some have significantly reduced seed germination (Figs. 5 and 6). Therefore, it would be better to avoid applying botanicals that inhibited seed germination to nurseries or along with basal-dressing when direct seeding is practiced. 


\section{Conclusion}

From the 10 botanicals tested, leaf powders of nutmeg, lantana, cinnamon, mee, and pepper were identified as materials with better potentials to suppress nitrification with minimum non-target effects. Based on the performance of botanicals in bioassays conducted with AOB isolates, it can be concluded that the success of botanical or synthetic NIs is greatly challenged by the diversity of ammonia-oxidizers in soil.

Cinnamon, nutmeg and pepper are minor exports crops which are much valuable in earning foreign exchange in Sri Lanka. Leaves removed during pruning of these crops are currently an agricultural waste. Lantana is also an invasive plant in some ecosystems in Sri Lanka. Therefore, using leaves of these plant species in crop cultivation as botanical NIs would be a value addition that promote resource circulation with underutilized agricultural waste.

\section{Conflict of Interest}

We declare that there is no conflict of interest.

\section{Author Contributions}

- $\quad$ Study concept and design: W.S.D.

- Analysis and interpretation of data: K.K.K.N., W.S.D., R.S.D., and P.W.

- $\quad$ Drafting of the manuscript: K.K.K.N. and W.S.D.

- Critical revision of the manuscript for important intellectual content: W.S.D., R.S.D., and P.W.

- $\quad$ Statistical analysis: K.K.K.N., W.S.D., and R.S.D.

- $\quad$ Obtained funding: W.S.D.

- $\quad$ Study supervision: W.S.D., R.S.D., and P.W.

\section{Acknowledgement}

Financial support provided by National Research Council of Sri Lanka (ID Grant NRC 16-075) and partial funding received from the Research Facilitation Fund of Postgraduate Institute of Agriculture, University of Peradeniya and University of Winnipeg QES grant are acknowledged. Authors wish to thank Ms. Samudi Hansika for the technical assistance provided for the laboratory analyses. Authors acknowledge Mr. Indrajee De Zoysa from the English Language Teaching Unit in the Faculty of Veterinary Medicine and Animal Science, University of Peradeniya, for the language editing service provided.

\section{References}

Amberger, A. 1989. Research on dicyandiamide as a nitrification inhibitor and future outlook. Commun. Soil Sci. Plant Anal. 20(19-20): 1933-1955.

Bollmann, A., Bär-Gilissen, M.J., and Laanbroek, H.J. 2002. Growth at low ammonium concentrations and starvation response as potential factors involved in niche differentiation among ammonia-oxidizing bacteria. Appl. Environ. Microbiol. 68(10): 4751-4757.
Boonsoong, B., and Bullangpoti, V. 2009. Toxicity of neem-based insecticides on non-target aquatic invertebrates: A mini review. Bio Pesticides Int. 5(2): 100-105.

Cataldo, D.A., Haroon, M., Schrader, L.E., and Youngs, V.L. 1975. Rapid colorimetric determination of nitrate in plat tissue by nitration of salicylic acid. Comm. Soil Sci. Plant Analy. 6: 71-80.

Di, H.J., and Cameron, K.C. 2004. Effects of temperature and application rate of a nitrification inhibitor, dicyandiamide (DCD), on nitrification rate and microbial biomass in a grazed pasture soil. Aust. J. Soil Res., 42(8): 927-932.

Gong, P., Zhang, L., Wu, Z., Shang, Z., and Li, D. 2013. Does the nitrification inhibitor dicyandiamide affect the abundance of ammonia-oxidizing bacteria and archaea in a Hap-Udic Luvisol. J. Soil Sci. Plant Nutr. 13(1): 35-42.

Gopalakrishnan, S., Subbarao, G.V., Nakahara, K., Yoshihashi, T., Ito, O., Maeda, I., and Yoshida, M. 2007. Nitrification inhibitors from the root tissues of Brachiaria humidicola, a tropical grass. J. Agric. Food. Chem. 55(4): 1385-1388.

Hart, S.C., Stark, J.M., Davidson, E.A., and Firestone, M.K. 1994. Nitrogen mineralization, immobilization, and nitrification. Meth. Soil Anal: Part 2 Microbiological and Biochemical Properties, SSSA Book Series, Soil Science Society of America, Madison, WI. USA. 5: 985-1018.

Jackson, M.L. 1958. Soil chemical analysis. Prentice Hall. Inc., Englewood Cliffs, NJ, 498. pp. 183-204.

Jatana, B.S., Kitchens, C., Ray, C., and Tharayil, N. 2020. Regulating the nutrient release rates from proteinaceous agricultural byproducts using organic amendments and its effect on soil chemical and microbiological properties. Biol. Fertil. Soils 56(6): 747-758.

Koops, H.P., Böttcher, B., Möller, U.C., Pömmerening-Röser, A., and Stehr, G. 1991. Classification of eight new species of ammonia-oxidizing bacteria: Nitrosomonas communis sp. nov., Nitrosomonas ureae sp. nov., Nitrosomonas aestuarii sp. nov., Nitrosomonas marina sp. nov., Nitrosomonas nitrosa sp. nov., Nitrosomonas eutropha sp. nov., Nitrosomonas oligotropha sp. nov. and Nitrosomonas halophila sp. nov. Microbiology (Reading) 137(7): 1689-1699.

Krümmel, A., and Harms, H. 1982. Effect of organic matter on growth and cell yield of ammonia-oxidizing bacteria. Arch. Microbiol. 133(1): 50-54.

Kumar, R., Devakumar, C., Sharma, V., Kakkar, G., Kumar, D., and Panneerselvam, P. 2007. Influence of physicochemical parameters of neem (Azadirachta indica A Juss) oils on nitrification inhibition in soil. J. Agric. Food. Chem. 55(4): 1389-1393.

Lathiff, M.A. and Upali, W.S.P.Y. 2010. Fertilizer recommendations for horticultural crops, Agriculture Press, Department of Agriculture, Peradeniya, 2011/02/J-14/B2500(E).

Leininger, S., Urich, T., Schloter, M., Schwark, L., Qi, J., Nicol, G.W., et al. 2006. Archaea predominate among ammoniaoxidizing prokaryotes in soils. Nature 442(7104): 806-809.

Majumdar, D. 2002. Suppression of nitrification and $\mathrm{N}_{2} \mathrm{O}$ emission by karanjin--A nitrification inhibitor prepared from karanja (Pongamia glabra Vent.). Chemosphere 47(8): 845-850.

Manandhar, S., Luitel, S., and Dahal, R.K. 2019. In vitro antimicrobial activity of some medicinal plants against human pathogenic bacteria. J. Trop. Med., Available from https:// doi.org/10.1155/2019/1895340 [Accessed on+30 April 2021].

Mapa, R.B., Somasiri, S. and Nagarajah, S. 1999. Soils of the wet zone of Sri Lanka, Soil Science Society of Sri Lanka.

Marsden, K.A., Scowen, M., Hill, P.W., Jones, D.L., and Chadwick, D.R. 2015. Plant acquisition and metabolism of the synthetic nitrification inhibitor dicyandiamide and naturally-occurring guanidine from agricultural soils. Plant Soil 395(1-2): 201-214.

Muema, E.K., Cadisch, G., Röhl, C., Vanlauwe, B., and Rasche, F. 2015. Response of ammonia-oxidizing bacteria and archaea to biochemical quality of organic inputs combined with 
mineral nitrogen fertilizer in an arable soil. Appl. Soil Ecol. 95: 128-139.

Nawarathna, K.K.K., Dandeniya, W.S., Dharmakeerthi, R.S., and Weerasinghe, P. 2019. Dynamics of nitrifiers in soils of intensively vegetable cultivated areas in Sri Lanka. Trop. Agric. Res. 30(3): 5-68.

Nawarathna, K.K.K., Dandeniya, W.S., Dharmakeerthi, R.S., and Weerasinghe, P. 2021. Vegetable crops prefer different ratios of ammonium-N and Nitrate- $\mathrm{N}$ in the growth media. Trop. Agricul. Res. 32(1): 95-104.

Nelson, D.W., and Sommers, L.E. 1996. Total carbon, organic carbon, and organic matter. Meth. Soil Anal. Part 3 Chem. Meth. 5: 961-1010.

Norton, J.M., and Ouyang, Y. 2019. Controls and adaptive management of nitrification in agricultural soils. Front. Microbiol. 10: 1931. Available from https://doi.org/10.3389/ fmicb.2019.01931 [Accessed on 30 April 2021].

Patra, D.D., Kiran, U., and Pande, P. 2006. Urease and nitrification retardation properties in natural essential oils and their by-products. Commun. Soil Sci. Plant Anal. 37(11-12): 1663-1673.

Prasad, R., Prasad, B., and Prasad, J. 1989. Effect of some nonedible oils on retardation of nitrification, yield and nitrogen uptake by rice (Oryza sativa) in calcareous soil. Ind. J. Agricul. Sci. 59(5): 291-294.

Prosser, J.I., and Nicol, G.W. 2012. Archaeal and bacterial ammonia-oxidisers in soil: the quest for niche specialization and differentiation. Trends Microbiol. 20(11): 523-531.

Punyawardena, B.V.R., Bandara, T.M.J., Munasinghe, M.A.K., Banda, N.J. and Pushpakumara, S.M.V. 2003. Agro-ecological regions of Sri Lanka. Natural Resource Management Centre, Department of Agriculture, Peradeniya, Sri Lanka.

Rawat, K.S., Srivastava, A., Bhatt, S.C., Pachauri, S.P., and Srivastava, P.C. 2017. Kinetics and adsorption-desorption behavior of AM nitrification inhibitor in mollisols. Commun. Soil Sci. Plant Anal. 48(8): 857-864.

Schmidt, E.L., and Belser, L.W. 1994. Autotrophic nitrifying bacteria. R.W. Weaver, S. Angle, P. Bottomley, D. Bezdic, S. Smith, A. Tabatabai, and A. Wollum, eds. Methods of soil analysis. Part 2. Microbiological and biochemical properties, SSSA Book Series, Soil Science Society of America, Madison, WI, USA.

Sivasakthy, K., and Gnanavelrajah, N. 2012. Organic nitrogen sources and nitrification inhibitors on leaching and phyto- accumulation of nitrate and yield of Amaranthus polygamous. World J. Agricul. Sci. 8(2): 208-211.

Spargo, J.T., Cavigelli, M.A., Mirsky, S.B., Maul, J.E., and Meisinger, J.J. 2011. Mineralizable soil nitrogen and labile soil organic matter in diverse long-term cropping systems. Nutr. Cycl. Agroecosyst. 90(2): 253-266.

Subbarao, G.V., Rao, I.M., Nakahara, K., Sahrawat, K.L., Ando, Y., and Kawashima, T. 2013. Potential for biological nitrification inhibition to reduce nitrification and $\mathrm{N}_{2} \mathrm{O}$ emissions in pasture crop-livestock systems. Animal 7(2): 322-332.

Sutton, S. 2011. Measurement of microbial cells by optical density. J. Validat. Technol. 17(1): 46-49.

Tanaka, J.P., Nardi, P., and Wissuwa, M. 2010. Nitrification inhibition activity, a novel trait in root exudates of rice. AoB PLANTS 2010: plq014, doi:10.1093/aobpla/plq014.

Tindaon, F., Benckiser, G., and Ottow, C.G. 2013. Side effects of nitrification inhibitors on non-target microbial processes in soils. J. Trop. Soils 16(1): 7-16.

Tomiyama, H., Ohshima, M., Ishii, S., Satoh, K., Takahashi, R., Isobe, K., et al. 2001. Characteristics of newly isolated nitrifying bacteria from rhizoplane of paddy rice. Microbes. Environ. 16(2): 101-108.

Volpi, I., Laville, P., Bonari, E., o di Nasso, N.N., and Bosco, S. 2017. Improving the management of mineral fertilizers for nitrous oxide mitigation: The effect of nitrogen fertilizer type, urease and nitrification inhibitors in two different textured soils. Geoderma, 307: 181-188.

Wardle, D.A., Nicholson, K.S., and Ahmed, M. 1992. Comparison of osmotic and allelopathic effects of grass leaf extracts on grass seed germination and radicle elongation. Plant Soil 140(2): 315-319.

Weil, R.R., Islam, K.R., Stine, M.A., Gruver, J.B., and SamsonLiebig, S.E. 2003. Estimating active carbon for soil quality assessment: A simplified method for laboratory and field use. Am. J. Alternative Agric., 18: 3-17.

Weiske, A., Benckiser, G., Herbert, T., and Ottow, J. 2001. Influence of the nitrification inhibitor 3, 4-dimethylpyrazole phosphate (DMPP) in comparison to dicyandiamide (DCD) on nitrous oxide emissions, carbon dioxide fluxes and methane oxidation during 3 years of repeated application in field experiments. Biol. Fertil. Soils 34(2): 109-117.

Zerulla, W., Barth, T., Dressel, J., Erhardt, K., von Locquenghien, K.H., Pasda, G., et al. 2001. 3, 4-Dimethylpyrazole phosphate (DMPP)-a new nitrification inhibitor for agriculture and horticulture. Biol. Fertil. Soils 34(2): 79-84. 